Article

\title{
Thymosin $\alpha 1$ Interacts with Hyaluronic Acid Electrostatically by Its Terminal Sequence LKEKK
}

\author{
Walter Mandaliti ${ }^{1}$, Ridvan Nepravishta ${ }^{1,2}$, Francesca Pica ${ }^{3}$, Paola Sinibaldi Vallebona ${ }^{3}$, \\ Enrico Garaci ${ }^{4}$ and Maurizio Paci ${ }^{1, *}$ \\ 1 Department of Chemical Sciences and Technologies, University of Rome "Tor Vergata", via della Ricerca \\ Scientifica 1, 00133 Rome, Italy; w.mandaliti@alice.it (W.M.); nepravishta@gmail.com (R.N.) \\ 2 School of Pharmacy, East Anglia University, Norwich NR4 7TJ, UK \\ 3 Department of Experimental Medicine and Surgery, University of Rome "Tor Vergata”, via Montpellier 1, \\ 00133 Rome, Italy; pica@uniroma2.it (F.P.); paola.sinibaldi@uniroma2.it (P.S.V.) \\ 4 San Raffaele Pisana Scientific Institute for Research, Hospitalization and Health Care, 00163 Rome, Italy; \\ garacienrico@gmail.com \\ * Correspondence: paci@uniroma2.it
}

Received: 1 October 2017; Accepted: 24 October 2017; Published: 27 October 2017

\begin{abstract}
Thymosin $\alpha 1(T \alpha 1)$, is a peptidic hormone, whose immune regulatory properties have been demonstrated both in vitro and in vivo and approved in different countries for treatment of several viral infections and cancers. T $\alpha 1$ assumes a conformation in negative membranes upon insertion into the phosphatidylserine exposure as found in several pathologies and in apoptosis. These findings are in agreement with the pleiotropy of $T \alpha 1$, which targets both normal and tumor cells, interacting with multiple cellular components, and have generated renewed interest in the topic. Hyaluronan (HA) occurs ubiquitously in the extracellular matrix and on cell surfaces and has been related to a variety of diseases, and developmental and physiological processes. Proteins binding HA, among them CD44 and the Receptor for HA-mediated motility (RHAMM) receptors, mediate its biological effects. NMR spectroscopy indicated preliminarily that an interaction of $\mathrm{T} \alpha 1$ with HA occurs specifically around lysine residues of the sequence LKEKK of T $\alpha 1$ and is suggestive of a possible interference of T $\alpha 1$ in the binding of HA with CD44 and RHAMM. Further studies are needed to deepen these observations because $\mathrm{T} \alpha 1$ is known to potentiate the T-cell immunity and anti-tumor effect. The binding inhibitory activity of T $\alpha 1$ on HA-CD44 or HA-RHAMM interactions can suppress both T-cell reactivity and tumor progression.
\end{abstract}

Keywords: Thymosin $\alpha 1$; CD44; RHAMM; thymic hormone

\section{Introduction}

Thymosin $\alpha 1$ (T $\alpha 1)$, a 28-amino acid polypeptide, is one of the peptides isolated for the first time from calf thymus extracts for which immune regulatory properties have been demonstrated both in vitro and in vivo [1-3]. It is acetylated on its N-terminus group and a sequence: Ac-SerAsp-Ala-Ala-Val-Asp-Thr-Ser-Ser-Glu-Ile-Thr-Thr-Lys-Asp-Leu-Lys-Glu-Lys-Lys-Glu-ValVal-Glu-Glu-Ala-Glu-Asn-OH. T $\alpha 1$ is cleaved by an asparagine endopeptidase (legumain, AEP) from the $N$-terminus of Prothymosin $\alpha$ [4]. Both T $\alpha 1[4,5]$ and legumain [6] are present in different tissues, suggesting that this process is a general process in mammalian tissues.

Importantly $T \alpha 1$ was recently proven to restore the functionality of the mutated form of the chlorine channel function in the cystic fibrosis [7], opening the way for a possible potent single molecule therapy of this pathology of cystic fibrosis.

Currently T $\alpha 1$ is approved in different countries for the treatment of several viral infections [8-11] and as an adjuvant for immune enhancement $[12,13]$. Moreover, it has also been developed for 
treatment of non-small cell lung cancer (NSCLC), hepatocellular carcinoma, acquired immune deficience syndrome (AIDS) and malignant melanoma [14,15].

A univocal mechanism of action of $T \alpha 1$ is still unknown since no specific receptors for $T \alpha 1$ have been identified. T $\alpha 1$ induces T-cell and dendritic cell (DC) maturation and interleukin (IL)-2 expression; it is also capable of upregulating the expression of some Toll-like receptors (TLRs) in murine DCs protecting mice from invasive aspergillosis in the MyD88 (myeloid differentiate factor 88)-dependent way [16-24]. T $\alpha 1$ activates a protein kinase C (PKC)-IкB kinase (TRAF6) that is an atypical signaling pathway activating nuclear factor- $\mathrm{kB}$ and initiating the cytokine gene expression in murine bone marrow-derived macrophages [21].

Recent studies with model membranes indicate that $T \alpha 1$, unstructured in water solution, assumes tracts of helical conformation in structuring solvents like trifluoroethanol $[25,26]$. Interestingly, it assumes a conformation with two helical domains and inserts the first 5 residues of the $N$-terminal helix [27-30] in negative membranes models and particularly upon the phosphatidylserine (PS) exposure as found in several pathologies and apoptosis [31].

These findings are in agreement with a growing body of evidence attesting the pleiotropy of this hormone peptide, which targets both normal and tumor cells interacting with multiple cellular components [16-24]; as such, they have generated a renewed interest. Studies of the serum T $\alpha 1$ levels and of its interaction with soluble proteins [23,29] have also raised questions about the transport and localization of $\mathrm{T} \alpha 1$ in tissues and of the dynamics underlying the biological effects of this peptide in different clinical situations. All this research would benefit from a greater understanding of the T $\alpha 1$ conformation and of the mechanism(s) involved in the interactions with other components of cells.

Hyaluronan (HA) [32] is a large, glycosaminoglycan containing repeating disaccharide units of $\mathrm{N}$-acetyl glucosamine and glucuronic acid; it occurs ubiquitously in the extracellular matrix and on cell surfaces and is critical for maintaining their structure. While its structure is simple, HA is an extraordinarily versatile macromolecule. Its biosynthesis has been related to a variety of diseases as well as their developmental and physiological processes [32-34]. A number of cell-associated and extracellular HA binding proteins have been described as mediating the biological effects of HA [35], among them CD44 [36-44] and RHAMM [45-47]. Although information on the structure of these proteins is available, the specific requirements for their binding to HA is only available for CD44. HA can exist in high or low molecular weight forms due to cleavage into varying lengths. HA is considered the major ligand for CD44 and can bind CD44v isoforms that are ubiquitously expressed. Through binding of CD44, HA can activate cytoskeleton and matrix metalloproteinases signaling involved in tumor progression.

CD44 is a broadly distributed cell surface glycoprotein found on hematopoietic cells, fibroblasts, and numerous tumor cells and has seven extracellular domains, a transmembrane domain, and a cytoplasmic domain [42]. The CD44 variant v6 in particular promotes tumor progression and metastatic potential in some cancers. The extracellular structure contains clusters of conserved basic residues (BX7B motif) that are implicated in HA binding and located in the amino-terminal region in all isoforms [38-44].

RHAMM, the Receptor for HA-mediated motility, is a basic and coiled coil protein designated as CD168 and is located extra and intracellularly, including a HA-binding region with the same BX7B motif near its C-terminus [45-47].

HA may interact independently with both CD44 and RHAMM by common amino acid sequences [46]. It can induce numerous cell behaviors but specific inhibitors of these interactions are not available, thus the physiological functions of HA were deduced from the biological effects of some HA-receptor antagonists eventually blocking the interactions of HA with either CD44 or RHAMM [48-51]. Thus, it was hypothesized that it is likely that peptides able to bind HA can alter the HA-binding capacity of HA receptors [48]. Different HA-binding peptides have been proposed as specific, thus preventing leukocyte adhesion to HA and inhibiting leukocyte recruitment during contact hypersensitivity [51-54]. 
Thus, we carried out a preliminary investigation herewith reported about some points of similarity between the residues in the sequence of T $\alpha 1$ and the common regions of CD44 and RHAMM able to bind HA [48-53]. Because a number of residues similar in their sequence were found, we considered the possibility that, at preliminary level, an interaction between $\mathrm{T} \alpha 1$ and HA can occur in these regions.

Thus, an investigation by NMR spectroscopy was carried out, making it possible to identify the modality of binding and the region of T $\alpha 1$ where the interaction with HA occurs. Moreover, T $\alpha 1$ is known to potentiate T-cell immunity and anti-tumor effect. The binding inhibitory activity of T $\alpha 1$ on HA-CD44 or HA-RHAMM interactions can suppress both T-cell reactivity and tumor progression.

\section{Results}

\subsection{The Comparison of the Aminoacidic Sequence between Thymosin $\alpha 1$ and the Common HA Binding Sites of} RHAMM and CD44

The interactions of HA with RHAMM and CD44 occur by a common binding motif, indicated as $\mathrm{BX}_{7} \mathrm{~B}$, where $\mathrm{B}$ are Arg or Lys residues and $\mathrm{X}$ any amino acid with no basic character. Specifically, three and two different HA binding motifs were reported for CD44 and RHAMM respectively [48]. It is important to note initially that in the amino acid sequence of the $\mathrm{T} \alpha 1$ a clear $\mathrm{BX} \mathrm{F}_{7} \mathrm{~B}$ motif is not present. Similarity between only some residues was found. In fact, in Figure 1 in the sequence comparison between T $\alpha 1$ and HA common binding motifs of both RHAMM and CD44 proteins we report the residues that appear in a similar position. It is possible to note that comparing the regions $41-45$, 153-162 and 711-719 of CD44 some other similarities are present. Some of similarities were also found in the alignment of T $\alpha 1$ with 743-750 and 721-731 sequences of RHAMM.

\begin{tabular}{|c|c|}
\hline $\begin{array}{l}\text { CD44 (40-4 8) } \\
\text { Thymosin-a1 }\end{array}$ & 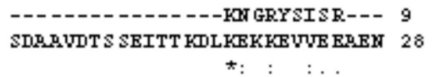 \\
\hline $\begin{array}{l}\text { CD44 (153-165) } \\
\text { Thymosin-a1 }\end{array}$ & 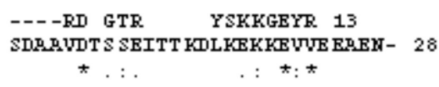 \\
\hline $\begin{array}{l}\text { CD44 (711-719) } \\
\text { Thymosin-a1 }\end{array}$ & 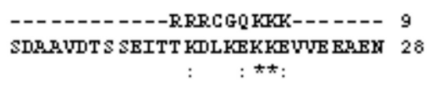 \\
\hline $\begin{array}{l}\text { RHPHF (741-750) } \\
\text { ThYm osin- a1 }\end{array}$ & 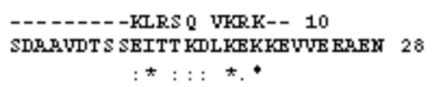 \\
\hline $\begin{array}{l}\text { RHPHH (719-729) } \\
\text { Thymosin- a1 }\end{array}$ & 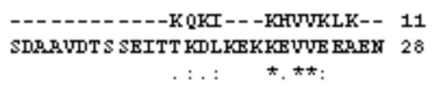 \\
\hline
\end{tabular}

Figure 1. Sequence comparison between the residues of Thymosin $\alpha 1$ and the common hyaluronan binding motifs of both CD44 (Mouse) and RHAMM (Mouse) as reported [48]. The symbols (*), (.) and (:) indicate identity, similarity and high similarity respectively between individual residues.

It is important to note that the tracts (40-48, 153-165) of CD44 appear in a link module [55]. The tracts involved in RHAMM appear first in a loop (741-750) and second (719-729) in a helix. It is important to note that the structure proposed for RHAMM is formed by three long helices without a well-defined tertiary structure.

The common feature among the different comparisons of amino acid sequence analysis reported in Figure 1 is the presence of similarity and/or identity of some residues in the C-terminal region of $\mathrm{T} \alpha 1$, particularly where the lysine residues are located. It is important to note that probably these residue side chains with positive charges are able to form ionic bridges with HA negative charges. 


\subsection{D NMR Studies: Structural Characterization of T 1 HA Interaction}

The ${ }^{1} \mathrm{H}$ NMR spectra of $\mathrm{T} \alpha 1(0.8 \mathrm{mM})$ in the presence of $\mathrm{HA}$ at the concentration of $0.4 \%(w / w)$ appear different with respect to the spectrum of the peptide in water solution. The differences observed in the amide region of the spectra, in particular the sharpening of the resonances in the presence of HA and the slight increase of the spectral dispersion, suggest that $\mathrm{T} \alpha 1$ interacts with $\mathrm{HA}$, undergoing a partial structuration event removing the slow exchange between different conformers as in the case of a random coil conformation (Figure 2). On the other hand, a broadening of the resonances without any spectral dispersion should be interpreted as an aspecific binding between macromolecules.

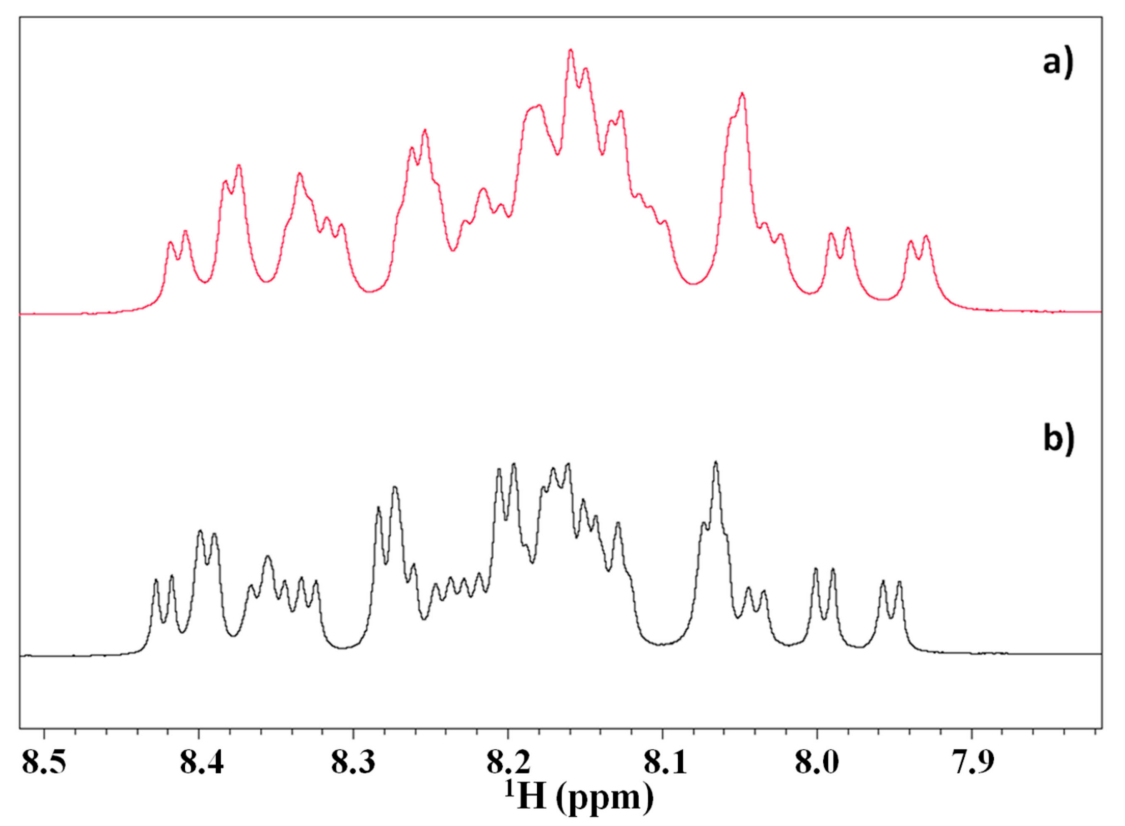

Figure 2. Amide protons region of the NMR spectra of (a) T $\alpha 1$ in water; (b) T $\alpha 1$ in presence of HA $0.4 \%(w / w)$.

The individual and sequential assignments of T $\alpha 1$ were obtained by TOCSY and NOESY experiments with different mixing times as reported in the Materials and Methods. Heteronuclear 2D NMR spectra $\left({ }^{15} \mathrm{~N}-\mathrm{HSQC}\right)$ at natural abundance (Figure 3a) were used to overcome ambiguities and complete the assignments of the homonuclear 2D NMR spectra using the previously reported results [27-30]. The appearance of NOEs in the NH-NH region of the NOESY spectra reported in Figure $3 \mathrm{~b}$ allowed us to carry out the sequential assignment of the peptide; intense $\mathrm{NH}-\mathrm{NH}(\mathrm{i}, \mathrm{i}+1)$ NOEs strongly suggest the presence of a helical conformation [56].

After the complete assignments obtained on the basis of previous work on T $\alpha 1$ [25-30] the preliminary analysis of the ${ }^{15} \mathrm{~N}$ chemical shift by the algorithm of Wishart and Sykes corrected for short peptides [57] confirmed values characteristic of the presence of a short tract in helical conformation from residue Ser1 to Val5 in presence HA at $0.4 \%(w / w)$ concentration (Figure 3c).

Thus, the 2D NMR assignments, the sequential NH-NH NOEs diagnostic of helix conformation [56] and the results of the chemical shift index protocol all revealed the existence of a tract helical conformation in the tract $1-5$ of the peptide with some residues in the C-terminal with some helical propensity. The extended conformation of the rest of $T \alpha 1$ is probably disordered, this being the best for the electrostatic binding to the periodic charges of HA as discussed below. 


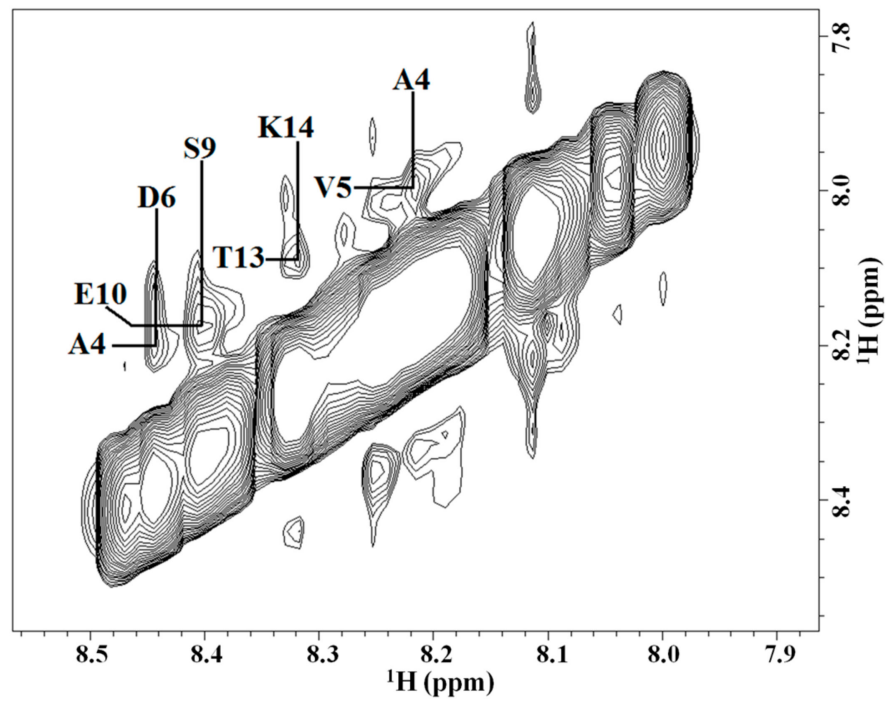

(a)

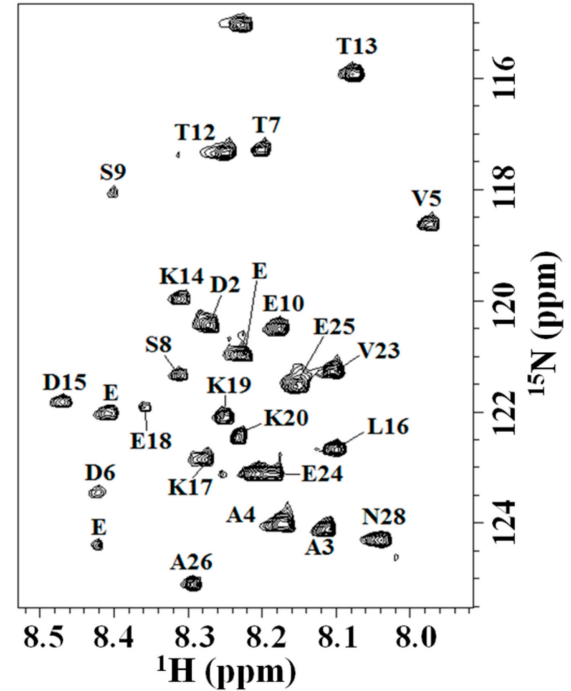

(b)

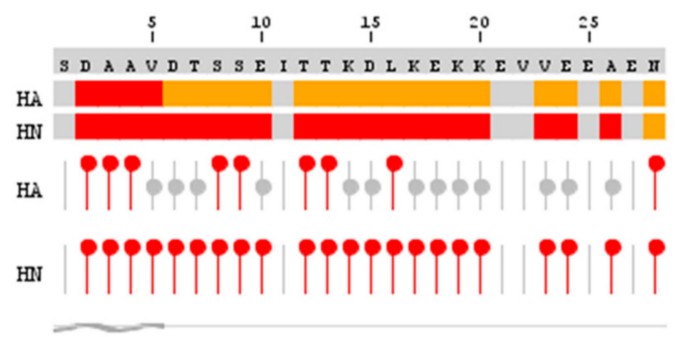

(c)

Figure 3. (a) NH-NH region of NOESY spectra of T $\alpha 1$ in presence of HA $0.4 \%(w / w) ;(\mathbf{b}){ }^{15} \mathrm{~N}-\mathrm{HSQC}$ of $\mathrm{T} \alpha 1$ at natural abundance of rare isotope of T $\alpha 1$ in presence of HA $0.4 \%(w / w)$ with individual assignments; (c) Chemical shift index (CSI) graphical representation obtained with the software NMRView according to Wright's protocol [57] (see text). The algorithm predicts a helical conformation in the tract $1-5$ of the peptide in presence of HA and an extended conformation in the rest of sequence. 


\section{Diffusion NMR Studies}

The Diffusion NMR spectra (DOSY) of T $\alpha 1(0.8 \mathrm{mM})$ in the presence of HA $(0.4 \%, w / w)$ and at two different dilution steps (1:3 and 1:2) of the initial sample were acquired (see Figure 4$)$. In the range of HA concentrations the marked differences of resonance intensity of the T $\alpha 1$ at different dilutions are to be considered dependent on the change of the spin-spin relaxation time of peptide. This NMR parameter is dependent on the changes of the peptide's tumbling, which can be directly attributed to the interaction of the peptide with the polysaccharide with a molecular weight higher than it. The measure at a different dilution but at the same molar ratio T $\alpha 1: H A$ resulted in a minimal change in diffusion, thus indicating that viscosity cannot be at the source of the value of the change of the diffusive front. This is to be attributed to the binding of T $\alpha 1$ to the high molecular weight HA (See Figure 4). From the relationship between diffusion coefficients correlation times and molecular weight, it is possible to estimate that about $55 \%$ of total $\mathrm{T} \alpha 1$ concentration is bound to $\mathrm{HA}$ in the range of concentrations studied using the Stokes-Einstein model. This value accounts for a binding constant of $\mathrm{Kd}$ of $\mathrm{T} \alpha 1$ about $2.2 \mathrm{mM}$. This value is in line with an electrostatic interaction.

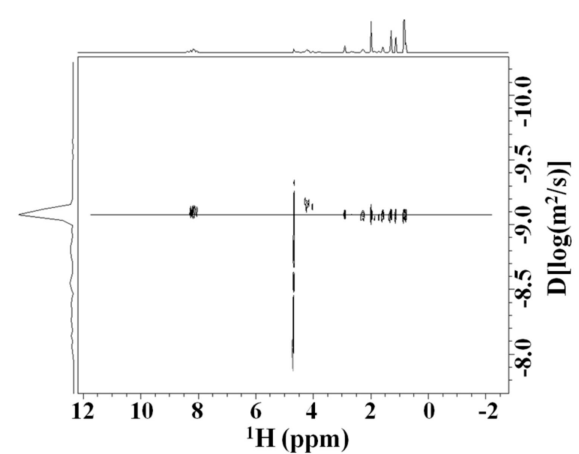

(a)

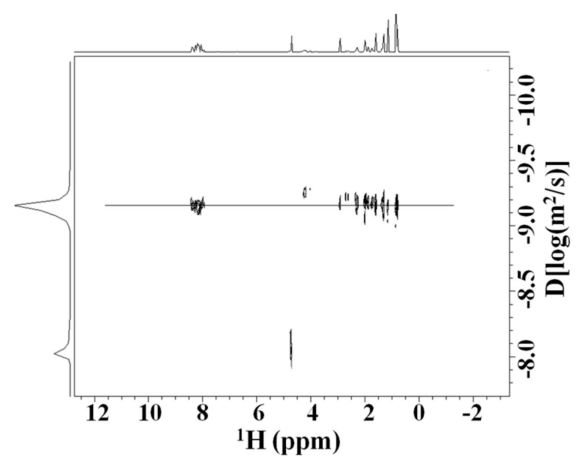

(b)

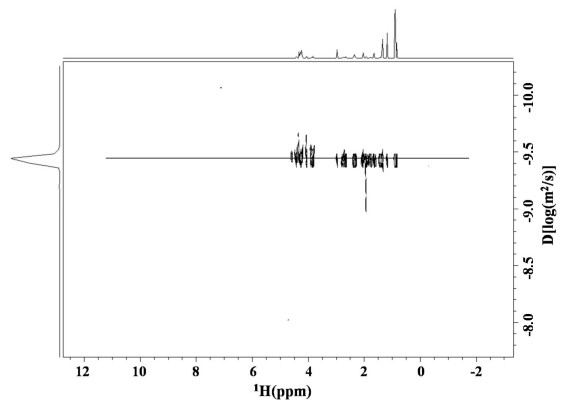

(c)

Figure 4. Molecular diffusion by NMR (DOSY spectra) of T $\alpha 1$ in water solution (a) alone; (b) in presence of $\mathrm{HA} ;(\mathbf{c})$ in the presence of the same concentration of dextransulfate.

As a control the diffusion measure was performed in the presence in the same concentration of dextransulfate, a polyanion. The change of the diffusive front was clearly observed as reported in Figure $4 \mathrm{c}$. In fact, the diffusion coefficient of $\mathrm{T} \alpha 1$ goes from the value of -9.08 in $\log \left(\mathrm{m}^{2} / \mathrm{s}\right)$ units to -9.18 in the presence of HA to -9.41 in the presence of dextransulfate. This marked decrease in diffusivity should be due to the large electrostatic interaction of $T \alpha 1$ with the negative charges of the polymer. It is important to remember that HA has alternating positive and negative charges every dimer. This is in line with the attribution to the interaction observed to an electrostatic interaction.

\subsection{Magnetization Transfer by WaterLOGSY}

In order to further investigate the interaction between $T \alpha 1$ and HA the magnetization transfer by water saturation experiments were performed. The results of application of the WaterLOGSY method 
are reported in Figure 5. Particularly this NMR experiment makes it possible to obtain information about the specific residues of T $\alpha 1$ involved in the interaction with HA.

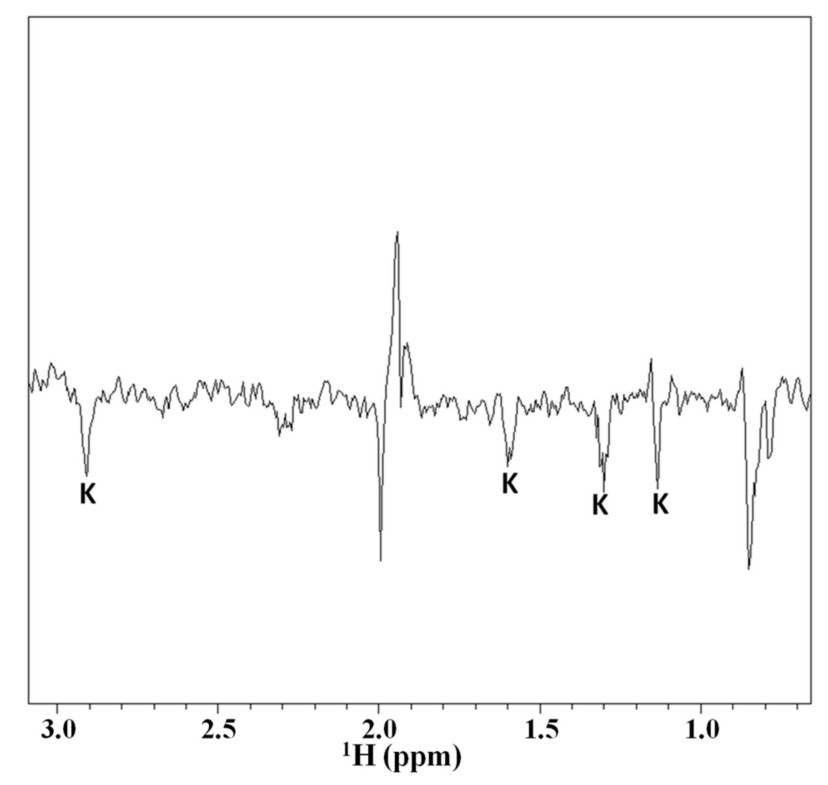

Figure 5. WaterLOGSY spectra obtained with $\mathrm{T} \alpha 10.8 \mathrm{mM}$ and $\mathrm{HA} 0.4 \%(w / w) \mathrm{H}_{2} \mathrm{O} / \mathrm{D}_{2} \mathrm{O}(90 \% / 10 \%)$, the symbol $\mathrm{K}$ indicated the lysine proton resonances in the residue side chain.

In fact, in WaterLOGSY sequence the selective saturation of the water signal determines, in addition to others cross-relaxation pathways, a specific magnetization transfer between the water near to the binding site of a macromolecule (usually present in sub-stoichiometric amount) and the proton(s) of a certain ligand. Therefore, in the WaterLOGSY spectra are visible only the resonances due to protons of the ligand involved in the interaction with the macromolecule. The utility of this method is widely documented in literature in the studies of interaction between small molecules and macromolecules, such as DNA, RNA and proteins. The results of the application of the WaterLOGSY spectra reported in Figure 6 indicate that a magnetization transfer to all the resonances of the lysine side chains $(\varepsilon, \gamma, \delta$, and $\beta$ respectively) occurs, clearly suggesting that the lysine residues of $T \alpha 1$ are directly involved in the interaction with the HA polymer.

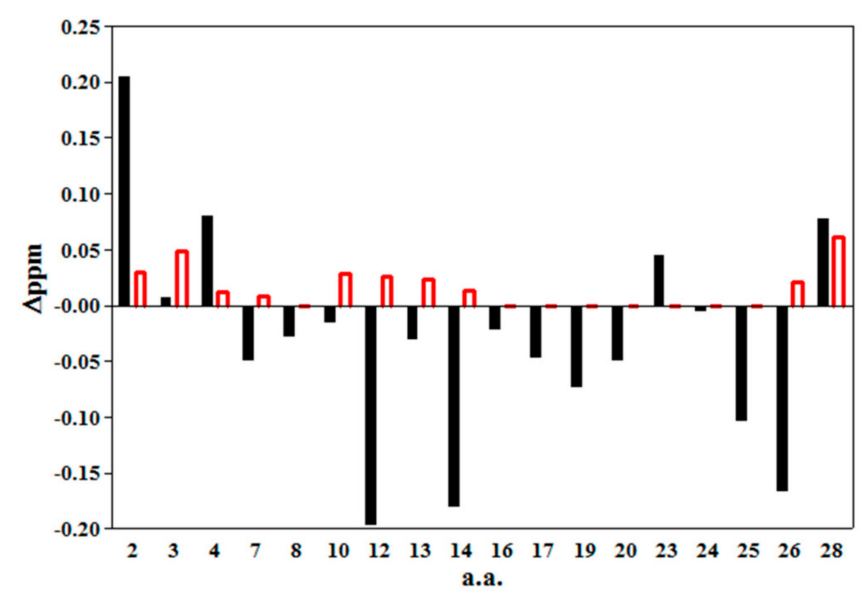

(a)

Figure 6. Cont. 


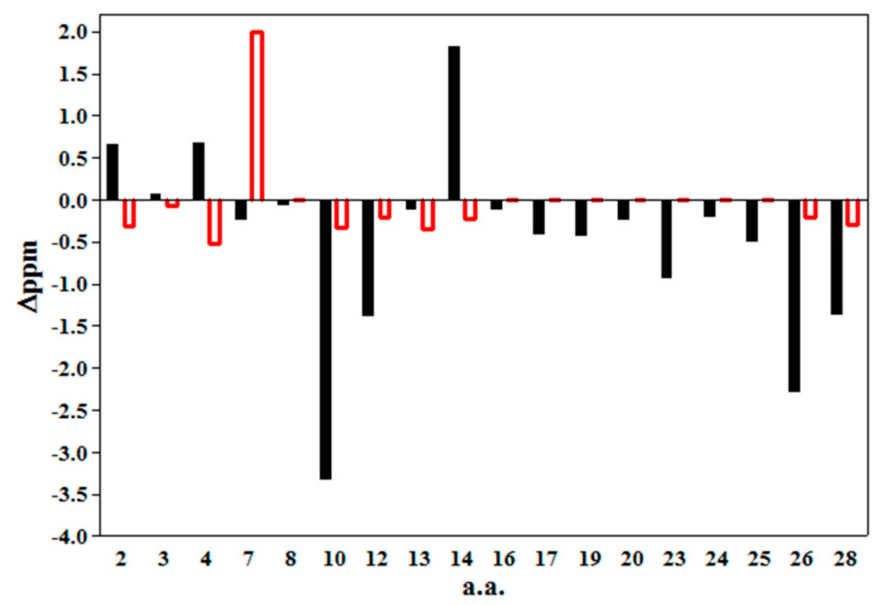

(b)

Figure 6. Bar graphs of Chemical shift difference between amide resonances of $\mathrm{T} \alpha 1$ in presence of PC-PS vesicles (black) and in presence of HA at a concentration of $0.4 \%(w / w)$ (red) (a); chemical shifts of amide proton and (b) chemical shifts of amide nitrogen.

\subsection{Structuration Propensity of Thymosin a1: In Phospholipidic Vesicles and in Presence of Hyaluronic Acid}

The chemical shift displacement of the amides resonances of $T \alpha 1$, assigned in the natural abundance ${ }^{15} \mathrm{~N}-\mathrm{HSQC}$ spectra of the rare isotope, in presence of phosphatidylcholinephosphatidyserine (PC-PS) vesicles and in the presence of HA with respect to the same resonances of the peptide in glucose solution were monitored (spectra not shown). The bar graphs of the NH and the ${ }^{15} \mathrm{~N}$ displacements, see Figure $6 \mathrm{a}, \mathrm{b}$ respectively, suggest that $\mathrm{T} \alpha 1$ in presence of HA shows a much smaller structuration effect in respect to the $T \alpha 1$ in the presence of phospholipidic vesicles.

The graphs report the chemical shift perturbations $[57,58]$ and confirm the slight structuration propensity only in the 1-5 tract of T $\alpha 1$ in presence of HA with the remaining part remaining substantially in an extended conformation.

It is important to note that the "lysine region" (K14-K20) of T $\alpha 1$ belonging to this region appears with a rather low structuration when it is involved in the interaction with HA, so confirming the results obtained by the WaterLOGSY.

It is important to remember that lysine residues are present in a tract with residues with similarity between T $\alpha 1$ and the sequence able to bind HA of CD44 and RHAMM [46]. Overall the NMR studies gave a preliminary result that T $\alpha 1$ interacts with HA by lysine residues, present in its C-terminal tract, accompanying a short helical structuration of the peptide's tract $1-5$.

\section{Discussion}

The results indicate that $T \alpha 1$ has a similarity of sequence with the sequences common to both CD44 and RHAMM that interact with HA. These peptides have both been studied with different strategies $[45,46,48]$ and by computer-aided design methods [59]. It was found that an octapeptide can bind to the HA binding domains of RHAMM. The docking experiments found that these peptides preferentially bound to the second helix forming three salt bridges between HA carboxylates and lysines side chains of RHAMM. Many results have been reported about these peptides together with some clusters of conserved basic residues (BX7B motif) [46-49].

Our approach started out from the sequence comparison between $\mathrm{T} \alpha 1$ with the common sequence found in the HA binding regions of CD44 and RHAMM [46-49]. The interaction of T $\alpha 1$ with HA was investigated by NMR spectroscopy ${ }^{1} \mathrm{H}$ and ${ }^{15} \mathrm{~N}$ HSQC and NMR diffusion studies. The results initially indicated that T $\alpha 1$ interacts with HA. The NMR results confirm the direct involvement of the "lysine region" of the peptide in the interaction with hyaluronic acid, as suggested by WaterLOGSY NMR 
spectra. Upon binding, T $\alpha 1$ assumes a very short helical structure in the $N$-terminus region while the remaining tract appears in an extended conformation including the region involved in the binding HA that contains the lysine residues. This is likely the region contains the LKEKK motif, which is the sequence also revealed in the sequence comparison above.

Consistently, the synthetic peptide LKEKK corresponding to sequence 16-20 of human T $\alpha 1$ and 131-135 of human interferon- $\alpha 2$ labeled with tritium binds with high affinity at nanomolar Kd T-lymphocytes [60]. Based on these findings it has been proposed that this fragment is responsible for T $\alpha 1$ and IFN- $\alpha 2$ binding to various cells and that synthetic LKEKK peptide has similar binding capacity and exhibits biological activity.

The evidence of intermolecular interactions and their modalities presented in this paper, though absolutely preliminary, are a novelty in the field of $\mathrm{T} \alpha 1$. These studies are only indicative of a possible involvement of $\mathrm{T} \alpha 1$ in electrostatic interactions that may influence the HA binding with the specific receptors CD44 and RHAMM alone and in their complex interplay. Obviously, these results need to be validated by tests able to identify the biochemical pathways influencing the several activities of HA in modulating CD44 and RHAMM biological functions.

In fact, chemotherapeutic drugs and stimulatory cytokines are used to mobilize to the circulation hematopoietic progenitor cells in the blood, but the mechanisms are largely unknown. Mobilization is almost certainly an active process which involves an initial step modulating adhesion receptors to permit detachment and a second step in which motile behavior is stimulated to permit migration [61,62]. Hyaluronan can play a key role in structuring tissue architecture, and is an important component in motility of normal and malignant hematopoietic cells, including T-cells, B cells, monocytes, and thymocytes. CD44, a receptor for HA, has been shown to participate in the adhesion of normal and malignant stem cells to the extracellular matrix.

RHAMM, another receptor for HA mediated motility, regulates cell cycling, transduces signals, and dissolves focal adhesions. In contrast to CD44, RHAMM mediates motility, or de-adhesion of all hematopoietic cells tested to date; this suggests that RHAMM interactions with HA may facilitate migratory behavior, whereas CD44 interactions with HA may facilitate anchoring [61,62].

It is interesting to note that in some reports $\mathrm{T} \alpha 1$ somehow influences most of these processes. In fact, $\mathrm{T} \alpha 1$ has been shown capable of increasing lymphocytic infiltration to sites of disease [63-67] while a correlation between tumor-infiltrating lymphocytes and prognosis for patients with stage IV cancer has been documented [68]. Moreover, T $\alpha 1$ can reduce apoptosis of immune cells, as shown in mouse $[69,70]$ and human $[71,72]$ thymocytes, and increase stem cell expansion in immunosuppressed mice [73-75].

These findings explain the therapeutic efficacy of T $\alpha 1$ in several types of cancer, especially in combination therapy protocols [64], based on its dual action on immune effector and tumor cells. The increase in effectiveness of chemotherapy has been linked to the T $\alpha 1$-induced increase in tumor infiltrating lymphocytes, upregulation of antitumor T-cells and enhanced expression of cell-surface and tumor markers, with a consequent increased tumor cell immunogenicity. The decrease in side effects of chemotherapy has been linked to the T $\alpha 1$ immuno-restorative properties, such as its ability to induce maturation, differentiation and function of immune effector cells and to increase regulatory T-cells with consequent decreases in pro-inflammatory cytokines [75].

The above biological actions may also contribute to explaining the therapeutic efficacy of T $\alpha 1$ in other physio-pathological conditions associated with immunological dampening and persistent inflammation, such as chronic viral hepatitis, severe sepsis, primary or acquired immuno-deficiencies and aging [13].

In this scenario, new questions arise. Further research on the interaction of T $\alpha 1$ with cell surface receptors and key extracellular matrix components is needed for a better understanding of the mechanisms involved in the multiple biological effects of this peptide on immune response, inflammation, cancer and chronic hepatitis, also in relation to the remodeling of tumor microenvironment and the mechanisms involved in tissue repair [75]. In this regard the interaction 
of T $\alpha 1$ with HA is highly intriguing, considering the ability of hyaluronan to act as a ligand for some receptors on cell membranes and to control cell cycle and tumor progression. In fact, cell-based experiments liking pre-incubation of T $\alpha 1$ with HA on T-cell responses (such as cell proliferation, cytokine production ... etc.) in comparison to HA-treated or T $\alpha 1$-treated T-cell alone may give important information. These preliminary results need, however, to be confirmed, substantiated and verified by a complex work in cell cultures by the laboratory experiments beyond the study in vitro.

\section{Materials and Methods}

The authors declare that the research did not involve Human Participants and/or Animals.

Thymosin $\alpha 1$ was a generous gift of SciClone Pharmaceuticals, Inc. (San Mateo, CA, USA). Sodium hyaluronate "High MW" with a value about MW $\geq 500 \mathrm{kDa}$ for pharmaceutical and medical use was purchased from "htl", Javené, France.

\subsection{Sequence Homology}

The alignments between Thymosin $\alpha 1$ and different regions of CD44 and RHAMM proteins were performed using ClustalOmega program, available in the UniProt web site [76].

\subsection{Preparation of Samples for NMR Measurements}

For two-dimensional (2D) NMR and WaterLOGSYspectra the sample contained T $\alpha 1$ and HYA at a concentration of $0.8 \mathrm{mM}$ and $0.4 \%(w / w)$ respectively, with $\mathrm{D}_{2} \mathrm{O}$ at $7 \%$ for lock signal. The DOSY NMR spectra were acquired on the same sample and at two different dilutions steps, of 1:3 and 1:2. The control with dextran sulfate was obtained by mixing $T \alpha 1$ with dextransulfate (Pharmacia, Uppsala, Sweden). The $\mathrm{pH}$ of all the solutions was adjusted to 6.5, and then the samples were placed into $5 \mathrm{~mm}$ NMR tubes for data collection at $298 \mathrm{~K}$ using sodium trimethylsilyl propionate (TSP) for internal reference.

\subsection{NMR Spectroscopy}

NMR spectra of $T \alpha 1$ alone and in the presence of HA were run at $298 \mathrm{~K}$ on a Bruker Avance instrument operating at $700.13 \mathrm{MHz} .{ }^{1} \mathrm{H}$ NMR spectra were performed with both the zgpr and zgpesgp pulse program of the Bruker library for water signal suppression, usually with 32 scans and a relaxation delay of $2 \mathrm{~s}$. Two-dimensional NMR experiments were performed in phase sensitive mode with a time proportional phase increment (States-TPPI) cycle [77] typically using $2 \mathrm{~K}$ of memory for 512 increments. The number of scans was optimized to obtain a satisfactory signal-to-noise ratio. Correlation experiments were performed with a TOCSY pulse sequence with the MLEV-17 spin-lock composite pulse sequence inserted [78,79] with mixing times of 60, 150, and $200 \mathrm{~ms}$. NOESY spectra were obtained using the classical pulse sequence $[56,80]$ with mixing times from 0.20 to $0.30 \mathrm{~s}$. A sine bell apodization function shifted typically by $\pi / 2$ in both dimensions was applied. In all homonuclear 2D experiments, a $1024 \times 1024$ matrix in phase sensitive mode was thus obtained with a digital resolution of $\sim 5 \mathrm{~Hz} /$ point. ${ }^{1} \mathrm{H}-{ }^{15} \mathrm{~N}-\mathrm{HSQC}$ [81] natural abundance spectra were acquired to confirm the assignments and to monitor the changes in T $\alpha 1$ amide groups in the different cases described (see Results). The TOPSPIN 3.1 and NMRView software packages were used for data processing and analysis. The Chemical Shift Index [56] calculations were performed using Wright's protocol incorporated into NMRView. The binding of T $\alpha 1$ to HA was investigated by a diffusion-ordered spectroscopy (DOSY) method $[82,83]$ and by WaterLOGSY NMR methods $[84,85]$. The DOSY spectra were recorded on a Bruker Avance instrument operating at $700.13 \mathrm{MHz}$ by using the ledbpgppr2s pulse sequence to suppress the water signal. During the DOSY experiment, 32 monodimensional spectra were acquired with 64 scans in a linear increasing gradient varying from 5 to $95 \%$ with a $\Delta$ of $70 \mathrm{~ms}$ and a $\delta$ of $2 \mathrm{~ms}$. The spectra were then analyzed using the DOSY module implemented in Bruker software TOPSPIN 3.1. The WaterLOGSY measurements were performed on a Bruker Avance instrument operating at $700.13 \mathrm{MHz}$ by using the pulse sequence proposed by Dalvit $[84,85]$ incorporating the 
Excitation Sculpting pulse scheme with gradients for water suppression [86]. The WaterLOGSY spectrum collected was the sum of 1024 scans.

Acknowledgments: The technical assistance of Fabio Bertocchi in the NMR instrumentation maintenance is gratefully acknowledged.

Author Contributions: W.M., R.N., M.P., F.P., S.V.P. and E.G. planned the investigation work. W.M.; R.N.; performed the analysis of the sequential similarity. W.M., R.N. and M.P. planned and carried out the NMR experiments, M.P., F.P., S.V.P. and E.G. discussed the results in the light of state of art research about in vitro tests and clinical application of Thymosin $\alpha 1$. All the Authors gave their consent to the publication.

Conflicts of Interest: The authors declare that they do not have any conflict of interest.

\section{References}

1. Goldstein, A.L.; Guha, A.; Zatz, M.M.; Hardy, M.A.; White, A. Purification and Biological Activity of Thymosin, a Hormone of the Thymus Gland. Proc. Natl. Acad. Sci. USA 1972, 69, 1800-1803. [CrossRef] [PubMed]

2. Low, T.L.; Thurman, G.B.; McAdoo, M.; McClure, J.; Rossio, J.L.; Naylor, P.H.; Goldstein, A.L. The chemistry and biology of thymosin. I. Isolation, characterization, and biological activities of thymosin alpha1 and polypeptide beta1 from calf thymus. J. Biol. Chem. 1979, 254, 981-986.

3. Low, T.L.; Goldstein, A.L. The chemistry and biology of thymosin. II. Amino acid sequence analysis of thymosin alpha1 and polypeptide beta1. J. Biol. Chem. 1979, 254, 987-995. [PubMed]

4. Sarandeses, C.S.; Covelo, G.; Díaz-Jullien, C. Prothymosin alpha is processed to thymosin $\alpha 1$ and thymosin $\alpha 11$ by a lysosomal asparaginyl endopeptidase. J. Biol. Chem. 2003, 278, 13286-13293. [CrossRef] [PubMed]

5. Franco, F.J; Diaz, C.; Barcia, M.; Freire, M. Thymosin $\alpha_{1}$ is a native peptide in several tissues. Biochim. Biophys. Acta 1992, 1120, 43-48. [CrossRef]

6. Chen, J.M.; Dando, P.M.; Rawlings, N.D.; Brown, M.A.; Young, N.E.; Stevens, R.A.; Hewitt, E.; Watts, C.; Barrett, A.J. Cloning, isolation, and characterization of mammalian legumain, an asparaginyl endopeptidase. J. Biol. Chem. 1997, 272, 8090-8098. [CrossRef] [PubMed]

7. Romani, L.; Oikonomou, V.; Moretti, S.; Iannitti, R.G.; D'Adamo, M.C.; Villella, V.R.; Pariano, M.; Sforna, L.; Borghi, M.; Bellet, M.M.; et al. Thymosin $\alpha 1$ represents a potentialpotent single-molecule-basedtherapy for cystic fibrosis. Nat. Med. 2017. [CrossRef] [PubMed]

8. Iino, S.; Toyota, J.; Kumada, H.; Kiyosawa, K.; Kakumu, S.; Sata, M.; Suzuki, H.; Martins, E.B. The efficacy and safety of thymosin alpha- 1 in Japanese patients with chronic hepatitis $B$; results from a randomized clinical trial. J. Viral Hepat. 2005, 12, 300-306. [CrossRef] [PubMed]

9. You, J.; Zhuang, L.; Cheng, H.Y.; Yan, S.M.; Yu, L.; Huang, J.H.; Tang, B.Z.; Huang, M.L.; Ma, Y.L.; Chongsuvivatwong, V.; et al. Efficacy of thymosin alpha-1 and interferon alpha in treatment of chronic viral hepatitis B: A randomized controlled study. World J. Gastroenterol. 2006, 12, 6715-6721. [CrossRef] [PubMed]

10. Andreone, P.; Cursaro, C.; Gramenzi, A.; Margotti, M.; Ferri, E.; Talarico, S.; Biselli, M.; Felline, F.; Tuthill, C.; Martins, E.; et al. In vitro effect of thymosin-alpha1 and interferon-alpha on Th1 and Th2 cytokine synthesis in patients with chronic hepatitis C. J. Viral Hepat. 2001, 8, 194-201. [CrossRef] [PubMed]

11. Kullavanuaya, P.; Treeprasertsuk, S.; Thong-Ngam, D.; Chaermthai, K.; Gonlachanvit, S.; Suwanagool, P. The combined treatment of interferon alpha-2a and thymosin alpha 1 for chronic epatitis $\mathrm{C}$ : The 48 weeks end of treatment results. J. Med. Assoc. Thail. 2001, 84 (Suppl. 1), S462-S468.

12. Carraro, G.; Naso, A.; Montomoli, E.; Gasparini, R.; Camerini, R.; Panatto, D.; Tineo, M.C.; De Giorgi, L.; Piccirella, S.; Khadang, B.; et al. Thymosin-alpha 1 (Zadaxin) enhances the immunogenicity of an adjuvated pandemic H1N1v influenza vaccine (Focetria) in hemodialyzed patients: A pilot study. Vaccine 2011, 30, 1170-1180. [CrossRef] [PubMed]

13. Goldstein, A.L. From lab to bedside: Emerging clinical applications of thymosin $\alpha 1$. Expert Opin. Biol. Ther. 2009, 9, 593-608. [CrossRef] [PubMed]

14. Maio, M.; Mackiewicz, A.; Testori, A.; Trefzer, U.; Ferraresi, V.; Jassem, J.; Garbe, C.; Lesimple, T.; Guillot, B.; Gascon, P.; et al. Large randomized study of thymosin $\alpha 1$, interferon alfa, or both in combination with dacarbazine in patients with metastatic melanoma. J. Clin. Oncol. 2010, 28, 1780-1787. [CrossRef] [PubMed]

15. Billich, A. Thymosin alpha1 SciClone Pharmaceuticals. Curr. Opin. Investig. Drugs 2002, 3, 698-707. [PubMed] 
16. Garaci, E.; Pica, F.; Serafino, A.; Balestrieri, E.; Matteucci, C.; Moroni, G.; Sorrentino, R.; Zonfrillo, M.; Pierimarchi, P.; Sinibaldi Vallebona, P. Thymosin $\alpha 1$ and cancer: Action on immune effector and tumor target cells. Ann. N. Y. Acad. Sci. 2012, 1269, 26-33. [CrossRef] [PubMed]

17. Serafino, A.; Pica, F.; Andreola, F.; Gaziano, R.; Moroni, N.; Moroni, G.; Zonfrillo, M.; Pierimarchi, P.; Sinibaldi-Vallebona, P.; Garaci, E. Thymosin $\alpha 1$ activates complement receptor-mediated phagocytosis in human monocyte-derived macrophages. J. Innate Immun. 2014, 6, 72-88. [CrossRef] [PubMed]

18. Giuliani, C.; Napolitano, G.; Mastino, A.; Di Vincenzo, S.; D’Agostini, S.; Grelli, C.; Bucci, I.; Singer, D.S.; Kohn, L.D.; Monaco, F.; et al. Thymosin- $\alpha 1$ regulates MHC class I expression in FRTL- 5 cells at transcriptional level. Eur. J. Immunol. 2000, 30, 778-786. [CrossRef]

19. Knutsen, A.P.; Freeman, J.J.; Mueller, K.R.; Roodman, S.T.; Bouhasin, J.D. Thymosin- $\alpha 1$ stimulates maturation of CD34+ stemcellsinto CD3+4+ cells in an in vitro thymic epithelia organ coculture model. Int. J. Immunopharmacol. 1999, 21, 15-26. [CrossRef]

20. Romani, L.; Bistoni, F.; Gaziano, R.; Bozza, S.; Montagnoli, C.; Perruccio, K.; Pitzurra, L.; Bellocchio, S.; Velardi, A.; Rasi, G.; et al. Thymosin $\alpha 1$ activates dendritic cells for antifungal Th1 resistance through toll-like receptor signaling. Blood 2004, 103, 4232-4239. [CrossRef] [PubMed]

21. Zhang, P.; Chan, J.; Dragoi, A.M.; Gong, X.; Ivanov, S.; Li, Z.W.; Chuang, T.; Tuthill, C.; Wan, Y.; Karin, M.; et al. Activation of IKK by thymosin $\alpha 1$ requires the TRAF6 signaling pathway. EMBO Rep. 2005, 6, 531-537. [CrossRef] [PubMed]

22. Leichtling, K.D.; Serrate, S.A.; Sztein, M.B. Thymosin $\alpha 1$ modulates the expression of high-affinity IL-2 receptor on normal human lymphocytes. Int. J. Immunopharmacol. 1990, 12, 19-29. [CrossRef]

23. Pica, F.; Chimenti, M.S.; Gaziano, R.; Buè, C.; Casalinuovo, I.A.; Triggianese, P.; Conigliaro, P.; Di Carlo, D.; Cordero, V.; Adorno, G.; et al. Serum thymosin $\alpha 1$ levels in patients with chronic inflammatory autoimmune diseases. Clin. Exp. Immunol. 2016, 186, 39-45. [CrossRef] [PubMed]

24. Romani, L.; Moretti, S.; Fallarino, F.; Bozza, S.; Ruggeri, L.; Casagrande, A.; Aversa, F.; Bistoni, F.; Velardi, A.; Garaci, E. Jack of all trades: Thymosin $\alpha 1$ and its pleiotropy. Ann. N. Y. Acad. Sci. 2012, 1269, 1-6. [CrossRef] [PubMed]

25. Grottesi, A.; Sette, M.; Palamara, T. The conformation of peptide thymosin $\alpha 1$ in solution and in a membrane like environment by circular dichroism and NMR spectroscopy. A possible model for its interaction with the lymphocyte membrane. Peptides 1998, 19, 1731-1738. [CrossRef]

26. Elizondo-Riojas, M.A.; Chamow, S.M.; Tuthill, C.W.; Gorenstein, D.G.; Volk, D.E. NMR structure of human thymosin alpha-1. Biochem. Biophys. Res. Commun. 2011, 416, 356-361. [CrossRef] [PubMed]

27. Nepravishta, R.; Mandaliti, W.; Eliseo, T.; Vallebona, P.S.; Pica, F.; Garaci, E.; Paci, M. Thymosin $\alpha 1$ inserts $\mathrm{N}$ terminus into model membranes assuming a helical conformation. Expert Opin. Biol. Ther. 2015, 2, 1-11. [CrossRef] [PubMed]

28. Mandaliti, W.; Nepravishta, R.; Vallebona, P.S.; Pica, F.; Garaci, E.; Paci, M. New studies about the insertion mechanism of Thymosin $\alpha 1$ in negative regions of model membranes as starting point of the bioactivity. Amino Acids 2016, 48, 1231-1239. [CrossRef] [PubMed]

29. Mandaliti, W.; Nepravishta, R.; Sinibaldi Vallebona, P.; Pica, F.; Garaci, E.; Paci, M. Thymosin $\alpha 1$ Interacts with Exposed Phosphatidylserine in Membrane Models and in Cells and Uses Serum Albumin as a Carrier. Biochemistry 2016, 15, 1462-1472. [CrossRef] [PubMed]

30. Nepravishta, R.; Mandaliti, W.; Sinibaldi Vallebona, P.; Pica, F.; Garaci, E.; Paci, M. Mechanism of action of Thymosin $\alpha 1$ : Does it interact with membrane by recognition of exposed phosphatidylserine on cell surface? A structural approach. Vitam. Horm. 2016, 102, 101-119. [PubMed]

31. Marino, G.; Kroemer, G. Mechanisms of apoptotic phosphatidylserine exposure. Cell Res. 2013, 23, 1247-1248. [CrossRef] [PubMed]

32. Fraser, J.R.; Laurent, T.C.; Laurent, U.B. Hyaluronan: Its nature, distribution, functions and turnover. J. Intern. Med. 1997, 242, 27-33. [CrossRef] [PubMed]

33. Shirali, A.C.; Goldstein, D.R. Activation of the innate immune system by the endogenous ligand hyaluronan. Curr. Opin. Organ Transplant. 2008, 13, 20-25. [CrossRef] [PubMed]

34. Senbanjo, L.T.; Chellaiah, M.A. CD44: A Multifunctional Cell Surface Adhesion Receptor Is a Regulator ofProgression and Metastasis of Cancer Cells. Front. Cell Dev. Biol. 2017. [CrossRef] [PubMed]

35. Toole, B.P. Hyaluronan and its binding proteins, the hyaladherins. Curr. Opin. Cell Biol. 1990, 2, 839-844. [CrossRef] 
36. Lesley, J.; Hascall, V.C.; Tammii, M.; Hyman, R. Hyaluronan Binding by Cell Surface CD44. J. Biol. Chem. 2000, 275, 26967-26975. [CrossRef] [PubMed]

37. Schwertfeger, K.L.; Cowman, M.K.; Telmer, P.G.; Turley, E.A.; McCarthy, J.B. Hyaluronan, Inflammation, and Breast Cancer Progression. Front. Immunol. 2015, 6, 236-238. [CrossRef] [PubMed]

38. Ponta, H.; Sherman, L.; Herrlich, P.A. CD44: From Adhesion Molecules to Signalling Regulators. Nat. Rev. Mol. Cell Biol. 2003, 4, 33-45. [CrossRef] [PubMed]

39. Louderbough, J.M.; Schroeder, J.A. Understanding the dual nature of CD44 in breast cancer progression. Mol. Cancer Res. 2011, 12, 1573-1586. [CrossRef] [PubMed]

40. Peterson, R.M.; Yu, Q.; Stamenkovic, I.; Toole, B.P. Perturbation of Hyaluronan Interactions by Soluble CD44 Inhibits Growth of Murine Mammary Carcinoma Cells in Ascites. Am. J. Pathol. 2000, 56, 2159-2167. [CrossRef]

41. Peach, R.J.; Hollenbaugh, D.; Stamenkovic, I.; Aruffo, A. Identification of Hyaluronic Acid Binding Sites in the Extracellular Domain of CD44. J. Cell Biol. 1993, 122, 257-264. [CrossRef] [PubMed]

42. Bourguignon, L.Y.; Shiina, M.; Li, J.J. Hyaluronan-CD44 interaction promotes oncogenic signaling, microRNA functions, chemoresistance, and radiation resistance in cancer stem cells leading to tumor progression. Adv. Cancer Res. 2014, 123, 255-275. [PubMed]

43. Perschl, A.; Lesley, J.; English, N.; Trowbridge, I.; Hyman, R. Role of CD44 cytoplasmic domain in hyaluronan binding. Eur. J. Immunol. 1995, 25, 495-501. [CrossRef] [PubMed]

44. Ghatak, S.; Hascall, V.C.; Markwald, R.R.; Misra, S. Stromal hyaluronan interaction with epithelial CD44 variants promotes prostate cancer invasiveness by augmenting expression and function of hepatocyte growth factor and androgen receptor. J. Biol. Chem. 2010, 285, 19821-19832. [CrossRef] [PubMed]

45. Yang, B.; Zhang, L.; Turley, E.A. Identification of Two Hyaluronan-binding Domains in the Hyaluronan Receptor RHAMM. J. Biol. Chem. 1993, 268, 8617-8623. [PubMed]

46. Yang, B.; Yang, B.L.; Savani, R.C.; Turley, E.A. Identification of a common hyaluronan binding motif in the hyaluronan binding proteins RHAMM, CD44 and link protein. EMBO J. 1994, 13, 286-296. [PubMed]

47. Misra, S.; Hascall, V.C.; Markwald, R.R.; Ghatak, S. Interactions between Hyaluronan and Its Receptors (CD44, RHAMM) Regulate the Activities of Inflammation and Cancer. Front. Immunol. 2015. [CrossRef] [PubMed]

48. Turley, E.A.; Naor, D. RHAMM and CD44 peptides-analytic tools and potential drugs. Front. Biosci. (Landmark Ed.) 2012, 17, 1775-1794. [CrossRef] [PubMed]

49. Tolg, C.; Hamilton, S.R.; Zalinska, E.; McCulloch, L.; Amin, R.; Akentieva, N.; Winnik, F.; Savani, R.; Bagli, D.J.; Luyt, L.G.; et al. A RHAMM mimetic peptide blocks hyaluronan signaling and reduces inflammation and fibrogenesis in excisional skin wounds. Am. J. Pathol. 2012, 181, 1250-1270. [CrossRef] [PubMed]

50. Esguerra, K.V.; Tolg, C.; Akentieva, N.; Price, M.; Cho, C.F.; Lewis, J.D.; McCarthy, J.B.; Turley, E.A.; Luyt, L.G. Identification, design and synthesis of tubulin-derived peptides as novel hyaluronan mimetic ligands for the receptor for hyaluronan-mediated motility (RHAMM/HMMR). Integr. Biol. 2015, 7, 1547-1560. [CrossRef] [PubMed]

51. Mummert, M.E.; Mohamadzadeh, M.; Mummert, D.I.; Mizumoto, N.; Takashima, A. Development of a Peptide Inhibitor of Hyaluronan-Mediated Leukocyte Trafficking. J. Exp. Med. 2000, 192, 769-779. [CrossRef] [PubMed]

52. Liu, N.; Xu, X.M.; Chen, J.; Wang, L.; Yang, S.; Underhill, C.B.; Zhang, L. Hyaluronan-Binding Peptide Can Inhibit Tumor Growth by Interacting with Bcl-2. Int. J. Cancer 2004, 109, 49-57. [CrossRef] [PubMed]

53. Xu, X.M.; Chen, Y.; Chen, J.; Yang, S.; Gao, F.; Underhill, C.B.; Creswell, K.; Zhang, L. A Peptide with Three Hyaluronan Binding Motifs Inhibits Tumor Growth and Induces Apoptosis. Cancer Res. 2003, 63, 5685-5690. [PubMed]

54. Hamilton, S.R.; Fard, S.F.; Paiwand, F.F.; Tolg, C.; Veiseh, M.; Wang, C.; McCarthy, J.B.; Bissell, M.J.; Koropatnick, J.; Turley, E.A. The Hyaluronan Receptors CD44 and Rhamm (CD168) Form Complexes with ERK1,2 ThatSustain High BasalMotility in Breast Cancer Cells. J. Biol. Chem. 2007, 282, 16667-16680. [CrossRef] [PubMed]

55. Teriete, P.; Banerji, S.; Noble, M.; Blundell, C.; Wright, A.; Pickford, A.; Lowe, E.; Mahoney, D.; Tammi, M.; Kahmann, J.; et al. Structure of the Regulatory Hyaluronan-Binding Domain in the Inflammatory Leukocyte Homing Receptor CD44. Mol. Cell 2004, 13, 483-489. [CrossRef]

56. Wüthrich, K. NMR of Proteins and Nucleic Acids; John Wiley \& Sons: New York, NY, USA, 1986. 
57. Wishart, D.S.; Sykes, B.D.; Richards, F.M. The Chemical Shift Index: A Fast and Simple Method for the Assignment of Protein Secondary Structure through NMR Spectroscopy. J. Mol. Biol. 1991, 222, 311-333. [CrossRef]

58. Williamson, M.P. Using chemical shift perturbation to characterize ligand binding. Prog. Nucl. Magn. Reson. Spectrosc. 2013, 73, 1-16. [CrossRef] [PubMed]

59. Ziebell, M.R.; Prestwich, G.D. Interactions of peptide mimics of hyaluronic acid with the receptor for hyaluronan mediated motility (RHAMM). J. Comput. Aided Mol. Des. 2004, 18, 597-614. [CrossRef] [PubMed]

60. Navolotskaya, E.V.; Zinchenko, D.V.; Zolotarev, Y.A.; Kolobov, A.A.; Lipkin, V.M. Binding of Synthetic LKEKK Peptide to Human T-Lymphocytes. Biochemistry (Mosc.) 2016, 81, 871-875. [CrossRef] [PubMed]

61. Pilarski, L.M.; Pruski, E.; Wizniak, J.; Paine, D.; Seeberger, K.; Mant, M.J.; Brown, C.B.; Belch, A.R. Potential role for hyaluronan and the hyaluronan receptor RHAMM in mobilization and trafficking of hematopoietic progenitor cells. Blood 1999, 93, 2918-2927. [PubMed]

62. Turley, E.A.; Austen, L.; Vandeligt, K.; Clary, C. Hyaluronan and a cell-associated hyaluronan binding protein regulate the locomotion of ras-transformed cells. J. Cell Biol. 1991, 112, 1041-1047. [CrossRef] [PubMed]

63. Garaci, E.; Mastino, A.; Pica, F.; Favalli, C. Combination treatment using thymosin alpha 1 and interferon after cyclophosphamide is able to cure Lewis lung carcinoma in mice. Cancer Immunol. Immunother. 1990, 32, 154-160. [CrossRef] [PubMed]

64. Mastino, A.; Favalli, C.; Grelli, S.; Rasi, G.; Pica, F.; Goldstein, A.L.; Garaci, E. Combination therapy with thymosin alpha 1 potentiates the anti-tumor activity of interleukin-2 with cyclophosphamide in the treatment of the Lewis lung carcinoma in mice. Int. J. Cancer. 1992, 50, 493-499. [CrossRef] [PubMed]

65. Garaci, E.; Pica, F.; Mastino, A.; Palamara, A.T.; Belardelli, F.; Favalli, C. Antitumor effect of thymosin alpha 1 /interleukin-2 or thymosin alpha 1 /interferon alpha, beta following cyclophosphamide in mice injected with highly metastatic Friend erythroleukemia cells. J. Immunother. Emphas. Tumor Immunol. 1993, 13, 7-17. [CrossRef]

66. Clemente, C.G.; Mihm, M.C., Jr.; Bufalino, R.; Zurrida, S.; Collini, P.; Cascinelli, N. Prognostic value of tumor infiltrating lymphocytes in the vertical growth phase of primary cutaneous melanoma. Cancer 1996, 77, 1303-1310. [CrossRef]

67. Osheroff, P.L. The effect of thymosin on glucocorticoid receptors in lymphoid cells. Cell. Immunol. 1981, 60, 376-385. [CrossRef]

68. Baumann, C.A.; Badamchian, M.; Goldstein, A.L. Thymosin alpha 1 antagonizes dexamethasone and CD3-induced apoptosis of CD4+ CD8+ thymocytes through the activation of cAMP and protein kinase C dependent second messenger pathways. Mech. Ageing Dev. 1997, 94, 85-101. [CrossRef]

69. Ho, A.D.; Stehle, B.; Dietz, G.; Hunstein, W.; Hoffbrand, A.V. Terminal differentiation of cord blood lymphocytes induced by thymosin fraction 5 and thymosin alpha 1. Scand. J. Immunol. 1985, 21, 221-225. [CrossRef] [PubMed]

70. Ohta, Y.; Sueki, K.; Yoneyama, Y.; Tezuka, E.; Yagi, Y. Immunomodulating activity of thymosin fraction 5 and thymosin alpha 1 in immunosuppressed mice. Cancer Immunol. Immunother. 1983, 15, 108-113. [CrossRef] [PubMed]

71. Ohta, Y.; Tezuka, E.; Tamura, S.; Yagi, Y. Thymosin alpha 1 exerts protective effect against the 5-FU induced bone marrow toxicity. Int. J. Immunopharmacol. 1985, 7, 761-768. [CrossRef]

72. Hu, S.K.; Low, T.L.; Goldstein, A.L. Modulation of terminal deoxynucleotidyl transferase activity by thymosin. Mol. Cell. Biochem. 1981, 41, 49-58. [CrossRef] [PubMed]

73. Garaci, E.; Pica, F.; Matteucci, C.; Gaziano, R.; D’Agostini, C.; Miele, M.T.; Camerini, R.; Palamara, A.T.; Favalli, C.; Mastino, A.; et al. Historicalreview on thymosin $\alpha 1$ in oncology: Preclinical and clinicalexperiences. Expert Opin. Biol. Ther. 2015, 15 (Suppl. 1), S31-S39. [CrossRef] [PubMed]

74. Tuthill, C.W.; King, R.S. Thymosin Apha 1-A Peptide Immune Modulator with a Broad Range of Clinical Applications. Clin. Exp. Pharmacol. 2013, 3, 4.

75. Malinda, K.M.; Sidhu, G.S.; Banaudha, K.K.; Gaddipati, J.P.; Maheshwari, R.K.; Goldstein, A.L.; Kleinman, H.K. Thymosin alpha 1 stimulates endothelial cell migration, angiogenesis, and wound healing. J. Immunol. 1998, 160, 1001-1006. [PubMed]

76. Sievers, F.; Wilm, A.; Dineen, D.G.; Gibson, T.J.; Karplus, K.; Li, W.; Lopez, R.; McWilliam, H.; Remmert, M.; Söding, J.; et al. Fast, scalable generation of high-quality protein multiple sequence alignments using clustal omega. Mol. Syst. Biol. 2011. [CrossRef] [PubMed] 
77. Marion, D.; Wuthrich, K. Application of phase sensitive two-dimensional correlated spectroscopy (COSY) for measurements of (1)H-(1)H spin-spin coupling constants in proteins. Biochem. Biophys. Res. Commun. 1983, 113, 967-974. [CrossRef]

78. Bax, A.; Davis, D.G. MLEV-17-based two-dimensional homonuclear magnetization transfer spectroscopy. J. Magn. Reson. 1985, 65, 355-360. [CrossRef]

79. Braunschweiler, L.; Ernst, R.R. Coherence transfer by isotropic mixing: Application to proton correlation spectroscopy. J. Magn. Reson. 1983, 3, 521-528. [CrossRef]

80. Jeener, J.; Meier, B.H.; Bachmann, P.; Ernst, R.R. Investigation of exchange processes by two-dimensional NMR spectroscopy. J. Chem. Phys. 1979, 71, 4546-4553. [CrossRef]

81. Bodenhausen, G.; Reuben, D.J. Natural abundance nitrogen-15 NMR by enhanced heteronuclear spectroscopy. Chem. Phys. Lett. 1980, 69, 185-189. [CrossRef]

82. Morris, K.F.; Johnson, C.S., Jr. Diffusion-ordered two-dimensional nuclear magnetic resonance spectroscopy. J. Am. Chem. Soc. 1992, 114, 3139-3141. [CrossRef]

83. Cohen, Y.; Avram, L.; Frish, L. DiffusionNMR Spectroscopy in Supramolecular and Combinatorial Chemistry: An OldParameter-New Insights. Angew. Chem. Int. Ed. 2005, 44, 520-554. [CrossRef] [PubMed]

84. Dalvit, C.; Fogliatto, G.; Stewart, A.; Veronesi, M.; Stockman, B. WaterLOGSY as a method for primary NMR screening: Practicalaspects and range of applicability. J. Biomol. NMR 2001, 21, 349-359. [CrossRef] [PubMed]

85. Dalvit, C.; Pevarello, P.; Tatò, M.; Veronesi, M.; Vulpetti, A.; Sundström, M. Identification of compounds with bindingaffinity to proteins via magnetization transfer from bulk water. J. Biomol. NMR 2000, 18, 65-68. [CrossRef] [PubMed]

86. Hwang, L.; Shaka, A.J. Water suppressionthatworks. Excitationsculptingusingarbitrarywaveforms and pulsedfieldgradients. J. Magn. Reson. Ser. A 1995, 112, 275-279. [CrossRef]

Sample Availability: Samples of the compounds are available from the authors.

(C) 2017 by the authors. Licensee MDPI, Basel, Switzerland. This article is an open access article distributed under the terms and conditions of the Creative Commons Attribution (CC BY) license (http://creativecommons.org/licenses/by/4.0/). 